\title{
Cancer Stem Cells in Colorectal Cancer: Genetic and Epigenetic Changes
}

\section{Sanchita Roy ${ }^{1,2}$ and Adhip P N Majumdar ${ }^{1,2,3 *}$}

${ }^{1}$ John D Dingell VA Medical Centre, 4646 John R Street, Detroit, MI- 48201, USA

${ }^{2}$ Department of Internal Medicine, Wayne State University, Detroit, MI- 48201, USA

${ }^{3}$ Karmanos Cancer Centre, Wayne State University School of Medicine, Detroit, MI- 48201, USA

\begin{abstract}
Colorectal cancer (CRC), an age-related disease, is the third most common cancer in the world. Although sporadic CRC, that affects $80-85 \%$ of CRC patients, is a multi-step process initiated by APC gene mutation, it is becoming increasingly evident that a small sub-population of cells termed cancer stem/stem-like cells (CSCs/CSLCs) plays critical roles in the progression of this malignancy specially the recurrence and drug resistance. The current review will summarize genetic and epigenetic changes observed at different stages in the progression of sporadic CRC. In addition, roles of miRNAs that control gene expression and CSCs/CSLCs in regulating proliferation, differentiation, and survival of the colon cancer cells will be summarized.
\end{abstract}

Keywords: Colorectal cancer; Cancer stem like cell; Genetics; Epigenetics; miRNAs

\section{Introduction}

Colorectal cancer (CRC) is the third most common cancer in the world. Approximately 1.23 million individuals worldwide will develop CRC and 0.6 million people will die of it annually [1]. In the USA, the American Cancer Society has estimated that 103,170 new cases of colon and 40,290 of rectal cancers will be diagnosed in 2012 with an expected death of about 51,690 [2]. The majority of colon cancer arises sporadically, the incidence of which increases markedly after the age of 50 years; only about 25 percent of the hereditary cases occur earlier than the sporadic colon cancer [3].

Although the reasons for the age-related rise in sporadic CRC are not fully known, sedentary lifestyle, diet rich in red meat and unsaturated fats, high energy intake, alcohol consumption are considered to be the major risk factors [4]. Hereditary CRC are of two types: Familial Adenomatous Polyposis (FAP) including an Attenuated Form of Polyposis (AFAP), due to germline mutations in the APC gene [5], and Hereditary Nonpolyposis Colon Cancer (HNPCC)/Lynch Syndrome (LS), which is also caused by germline mutations in DNA Mis-match Repair (MMR) genes [6,7]. Some other hereditary CRC are not associated with an identifiable hereditary syndrome; they are collectively known as familial CRC [8].

Colorectal cancer arises from polyps which are the localized lesions (benign growth) projecting up the surrounding mucosa. Most colorectal polyps are hyperplastic. Adenomatous polyp or adenoma arising from glandular epithelium with dysplastic morphology and altered differentiation of epithelial cells are the precursor of carcinoma [9]. Only a few of adenomas develop into cancer over the years.

\section{Cancer Stem/Stem like Cells and Colorectal Cancer}

Despite the fact that surgery and subsequent chemotherapy can cure over $75 \%$ of colon cancer patients, more than $30 \%$ of these patients develop new neoplastic polyps, and $10 \%$ progress to frank second malignancy. The underlying biochemical and molecular mechanisms for the recurrence of CRC have not been fully are not elucidated.

It has been suggested that germline variants in CSC/CSLC genes give rise to altered gene function, which causes variation in tumor recurrence capacity and chemoresistance among patients [10]. CSCs/ CSLCs are defined as "a cell within a tumor that possesses the capacity to self-renew and to cause the heterogeneous lineages of cancer cells that comprise the tumor" [11]. However, this definition does not reveal the origin of CSCs/CSLCs-they may either originate from stem/ progenitor cell or from differentiated cells [12]. Hence, the terms "tumor-initiating cell" or "cancer stem-like cell" are recommended instead of "cancer stem cell".

The concept of CSCs/CSLCs in the maintenance and progression of many types of cancer is now well accepted and continues to gain credibility as more evidence is uncovered. The CSC/CSLC model proposes that a population of CSCs/CSLCs exists within the tumor which is able to self-renew and differentiate into transient amplifying cell before terminally differentiating [13]. CSCs/CSLCs isolated from different solid tumors, including the colon are usually identified by specific surface markers. Colon cancer stem or stem-like cells have been shown to express CD44, CD166, CD133 and ESA (epithelialspecific antigen, also known as EpCAM) surface markers [14,15]. Cells expressing these surface markers have the ability to form tumors at a much diluted concentration in SCID mice and histologically resemble the primary tumor from which they were derived [16]. Another characteristic of CSCs/CSLCs is their ability to invade and metastasize by acquiring epithelial-mesenchymal transition (EMT) phenotype that can be determined by examining the expression of E-cadherin and vimentin which represent the effectors for WNT and notch signaling [17]. We have reported that $\mathrm{Wnt} / \beta$-catenin signaling plays a critical role in regulating growth and maintenance of colon CSCs/CSLCs [18].

In vertebrate, somatic/adult stem cells are found practically in all tissues either replenishing dying cells or regenerating damage/injury. Most of the human malignancies arise from tissues containing an active stem cell population [19]. The stem cells are being increasingly

*Corresponding author: Adhip P N Majumdar, Ph.D., D.Sc., John D. Dingell VA Medical Center/Wayne State University, 4646 John R, Detroit, Michigan 48201 USA, Tel : (313)5764460; Fax: (313)5761112; E-mail: a.majumdar@wayne.edu

Received November 12, 2012; Accepted December 15, 2012; Published December 17, 2012

Citation: Roy S, Majumdar APN (2012) Cancer Stem Cells in Colorectal Cancer: Genetic and Epigenetic Changes. J Stem Cell Res Ther S7:006. doi:10.4172/21577633.S7-006

Copyright: @ 2012 Roy S, et al. This is an open-access article distributed under the terms of the Creative Commons Attribution License, which permits unrestricted use, distribution, and reproduction in any medium, provided the original author and source are credited. 
recognized as being the target of cancer initiating events as both genetic and epigenetic alterations could lead to the processes of carcinogenesis [20,21]. Aging increases the rate of DNA damage by impairing the DNA repairing systems. In one hand DNA damage in stem cells will decrease its number by apoptosis; on the other hand DNA damage leads to the accumulation of mutations and epimutations in surviving stem cells which are escaped through DNA repairing system. Accumulating mutations and epimutations augment the age-related neoplastic transformation, and affect stem cell function by altering transcriptome [22].

\section{Genetic Changes in Colorectal Cancer}

A series of deleterious molecular alterations is responsible for the transition from normal epithelium to carcinoma. CRC is a multistage process, involving multiple genetic changes that provide tumor cells with a selective advantage to expand their clones [23]. Genetic changes that occur at different stages of epithelial cell carcinoma have been extensively studied by Fearon and Vogelstein in human colon cancer $[24,25]$. Majority of CRCs result from chromosomal instability (CIN); $20 \%$ to $30 \%$ of CRCs display characteristic patterns of gene hypermethylation, termed $\mathrm{CpG}$ island methylator phenotype (CIMP), of which $15 \%$ of CRCs have microsatellite instability [26]. The spectrum of somatic mutations contributing to the pathogenesis of CRC is wide. Sixty-nine genes were identified as relevant to the pathogenesis of CRC. Nevertheless individual CRC carries an average of nine mutant genes per tumor. In addition, every tumor shows a distinct mutational gene signature [27]

CIN cancers are characterized by chromosome number (aneuploidy) with frequent detectable losses at the molecular level of portions of chromosome 5q, 17p, 18q; and mutation of the KRAS oncogene. The important genes involved in these chromosome losses are APC (5q), DCC/MADH2/MADH4 (18q), and TP53 (17p) [28] resulting in instability at the molecular and chromosomal levels (Lengauer et al.). One of the key events in the colorectal tumor progression is the loss of the APC gene, which appears to be consistent with germline mutation of the gene. Acquired or inherited mutations of DNA damage-repair genes (MMR) also affects colorectal epithelial cells to malignant transformation. The top somatic mutations in human colon cancer are in the following genes: APC, BRAF, CTNNB1/ beta-catenin, FBXW7, KRAS, PIK3CA, SRC, and P53.

\section{Epigenetic Phenomena Associated With Colorectal Cancer}

Epigenetic processes do not include changes in DNA sequence, but are potentially reversible genetic modifications leading to genomic instability and malfunction [29]. The estimated loss of epigenetic control may be one to two fold(s) more than that of somatic DNA mutations [30]. Epigenetics changes include: (i) altered DNA methylation, (ii) chromatin remodeling [31] and (iii) non-coding small RNA (miRNAs) [32]. Notable changes in epigenetics have been reported for several age-related diseases (ARDs), including CRC [33]. Three types of altered DNA methylation patterns are found in human cancer: hypomethylation, hypermethylation, and loss of imprinting (LOI) [34]. LOI refers to the loss of the differential expression of parental alleles, which is dominant in embryonal tumors [35]. The global DNA hypomethylation, hypermethylation of tumor-suppressor genes and inactivation of miRNA by DNA methylation also has been described in human tumors [36-38]. In fact, only about $10 \%$ of CRC are characterized by the "classic" genotype [39].

\section{DNA hypomethylation and colorectal cancer}

The degree of methylation of DNA has great impact on the process of carcinogenesis. Global DNA hypomethylation on their promoter induces expression of proto-oncogenes [40]. The global hypomethylation rate of $8-10 \%$ has been recorded in colon adenomas and adenocarcinomas [41]. CDH3 (P-cadherin) and CD133 genes are often demethylated in advanced colorectal carcinomas [42]. Increased hypomethylation of LINE-1 is also observed in colon carcinoma, compared to that noted in dysplastic polyp and histological normal colonic epithelium [43]. LOI is seen in about $40 \%$ of CRC tissue [44].

\section{DNA hypermethylation in colorectal cancer}

In the human genome about half of all protein-encoding genes contain CG-rich regions in their promoters or CpG islands called CpG Island Methylator Phenotype (CIMP). Aberrant hypermethylation of $\mathrm{CpG}$ islands represses transcription of tumor suppressor genes [45]. The role of CIMP in colorectal carcinogenesis was first described in 1999 by Toyota [46]. The CIMP+ CRC group contains more frequent KRAS but less TP53 mutations compared with the CIMP- group.

CDKN2A/p16 gene is more frequently methylated in lymphatic metastasis of CRC [47] and advanced CRC [48]. Wnt antagonist DKK-1 is methylated in advanced CRC [49]. APC and ESR1 promoter methylation are associated with metastatic colon cancer. Methylated APC is found in liver metastasis than in primary CRC [50], and ESR1 methylation is detected in resected lymph nodes from CRC patients with UICC stage I and II [51]. ID4 and HPP1/TPEF display a higher methylation in liver metastases compared to local CRC [52].

\section{miRNA}

Over the past decade, evidence has been accumulating showing that dysregulation of certain microRNAs, a class of endogenous small non-coding RNAs containing 19-22 nucleotides' that control gene expression usually through binding to the seed sequence at the 3'-UTR of target mRNAs, can also affect the functional properties of genes [53] For example, miRNA-21, an oncomir, which is upregulated in many solid tumors, including the colon, targets not only tumor suppressors genes such as tropomyosin 1 (TPM1) [54], phosphatase and tensin homolog (PTEN) [55], and programmed cell death 4 protein (PDCD4), but also other genes that are involved in suppression of invasion and metastasis. The latter includes maspin [56]. Expression of all these proteins in cancer cells was shown to be downregulated by elevated levels of miR-21, conversely inhibition of miR-21 decreased tumor cell growth, migration, and invasion [54-56]. Promoter of miR-21 contains binding sites for transcription factor STAT3 which is activated by IL-6 signaling pathway. Hence miR-21 expression is induced by IL-6 [57]. Upregulation of IL-6 is often observed in aging and tumorigenesis [58]. We have showed that miR21 induces stemness in colon cancer cells by downregulating TGF $\beta$ RII [59]. Additionally, we have observed that the levels of miR-21 are greatly elevated in 5-FU and Oxaliplatin resistant (chemo-resistant) colon cancer cells (unpublished observation). This is of particular significance since chemo-resistant colon cancer cells, which we have shown to be highly enriched in CSCs/CSLCs; $[60,61]$ are responsible for the development and progression of many malignancies, including CRC [62].

In contrast to miR21, the family of miR-34 including $34 \mathrm{a}, \mathrm{b}$ and c, are downregulated in CRC $[63,64]$. These tumor suppressive miRs (TSG miR) play critical role in progression of CRC and for drugresistance [65]. It has been demonstrated that p53 acts as transcription factor to increase the expression of the miR-34 family. Interestingly, 
the functional properties of $\mathrm{p} 53$ are under the influence of miR-34. In fact, a positive feedback loop is found to be present between p53 and miR-34a [66]. The p53-induced expression of miR-34a has been shown to inhibit its target gene SIRT1, a histone deacetylase [66]. Downregulation of SIRT1 expression up-regulates p53 acetylation and the transcriptional activity of p53 [67]. Expression of miR-34 induces cellcycle arrest, inhibition of invasion and migration and p53 induced apoptosis $[68,69]$.

\section{Histone modifications in the pathogenesis of colorectal cancer}

The nucleosome unit is consist of four core histone proteins, $\mathrm{H} 2 \mathrm{~A}$, $\mathrm{H} 2 \mathrm{~B}, \mathrm{H} 3$ and $\mathrm{H} 4$ forming an octamer wrapped by 147bp segment of DNA in 1.67 left-handed superhelical turns. Linker histones i.e. $\mathrm{H} 1$ helps to bind the DNA to the core particle. Highly basic histone $\mathrm{N}$-terminal domains protrude from the nucleosome. Eight different types of modifications have been noted in multiple sites of lysine and arginine residues of the free $\mathrm{N}$-terminal domains. They are acetylation, methylation, phosphorylation, ubiquitylation, sumoylation, ADP ribosylation, deimination and proline isomerization. Acetylation and methylation comprise of the majority of known modifications.

Acetylation occurs in lysine residues of the four core histones, counter balanced by the opposite effects of two main enzyme Histone Acetyltransferases (HATs) and Histone Deacetylases (HDACs). Substantial acetylation either results in the alteration of the electrostatic charge of histones and thus the chromatin structure (cis mechanism), or function as binding sites for bromodomain protein recognition motifs specific for recognizing acetylated lysine residues (trans mechanism) [70]. These conserved domains bind acetylated, non-histone polypeptides (such as transcription factors) to regulate intracellular signaling [71]. Global loss of acetylation of histone $\mathrm{H} 4$ at lysine $16(\mathrm{H} 4 \mathrm{~K} 16 \mathrm{ac})$ was the first histone modification reported in CRC [72]. Global hypoacetylation of $\mathrm{H} 4 \mathrm{~K} 12$ and $\mathrm{H} 3 \mathrm{~K} 18$ is associated with poorly differentiated colorectal adenocarcinomas [73]. H3K9 hypoacetylation is found in histological condition of metachronous CRC liver metastasis. Deacetylation of the same residue results if inactivation of the tumor suppressor gene E-cadherin in CRC cell lines [74]. $\mathrm{H} 3$ and $\mathrm{H} 4$ acetylation is critical for transcriptional activation of 15-lipoxygenase-1 (15-LOX-1); its trancript is downregulated in CRC cells [75]. Decrease of p21WAF1 transcription is associated with $\mathrm{H} 3$ hypoacetylation and histone enzymes in CRC [76]. Reduced H4 acetylation brings in silencing of $\mathrm{N}$-myc downstream-regulated gene 1 (NDRG1) in CRC metastasis [77].

Histone is methylated either as mono-, di- and tri-methylation on lysines or as mono- and di- methylation in arginines. Enzymes are classified as lysine and arginine histone methyl transferase (HMTs) and lysine histone demethylases (HDMs).

A hallmark of histone methylation in CRC is the loss of trimethylation at lysine 20 of histone $\mathrm{H} 4$ (H4K20me3) in primary tumors and in cell lines compared to normal mucosa [72]. H3K27me3 was reported to decrease the promoter activity of cyclin D1 independently of the high methyltransferase enzyme level [78]. Downregulation of $\mathrm{H} 3 \mathrm{~K} 4 \mathrm{me} 2$ in the coding region of NDRG1 in SW620 cells was correlated with down-regulation of NDRG1 expression in CRC metastasis [79]. H3K9 tri-methylation was found to be increased in HCT116 cells, possibly promoting silencing of tumor suppressor genes [80]. Over expression of G9a, a H3K9-specific p53 methyltransferase is reported in CRC among other types of cancer and it likely affects gene expression [81].

\section{Colonic Crypt Organization and Tumorigenesis}

The inner epithelial layer of the human colon is lined by a single layer of columnar epithelial cells, which form finger-like invaginations into the underlying connective tissue of the lamina propria, called crypt. Millions of crypts are present within the colon and stem-cells are located at the base of the crypt. When an initial mutation occurs in a basally situated crypt stem cell it generates mutant clone migrating up the crypt and colonizing at the base of the crypt, thereby replacing the non-mutant stem-cell. This process of taking over and replacing the normal stem cell niche with new clones is called niche succession [82]. Ultimately the entire niche will be colonized with mutant stem cells, and the crypt is filled by the progeny- this event is termed the monoclonal conversion [82].

The bottom-up model of colonic tumorigenesis as depicted in Figure 1A describes that unlike transit proliferative cells moving steadily towards the crypt surface, slow-dividing stem cells reside at the base of the crypt; thereby accumulating oncogenic mutations for a phase of pre-cancerous latent periods and subsequently gives rise to the transformed colonic epithelial cells a direct progeny of a mutant stem cell which in turn produce dysplastic crypts arising from the bottom of the crypt. Nevertheless, dysplastic cells are usually found at the luminal surface of the crypt while the cells at the bottom appear morphologically normal in the same crypt. To resolve this controversy Shin et al proposed the top-down model of colonic tumorigenesis (Figure 1B) [83]. They evaluated the molecular characteristics of cells isolated from the bases and orifices of the same crypt in small colorectal adenomas and found that the dysplastic cells at the top of the crypt often exhibited genetic alterations of adenomatous polyposis coli (APC) and neoplasia-associated patterns of gene expression whereas the cells located at the base of the same crypts neither had genetic alterations nor were clonally related to the contiguous transformed cells on the top. On the basis of these observations, they concluded that development of adenomatous polyps progresses through a top-down mechanism. Neoplasms are originated from the stem cells located in the inter-cryptal zones i. e. between crypt orifices rather than those residing at the base of the crypts [84]. Genetically modified cells in the superficial part of the mucosa migrate laterally and downward to
A

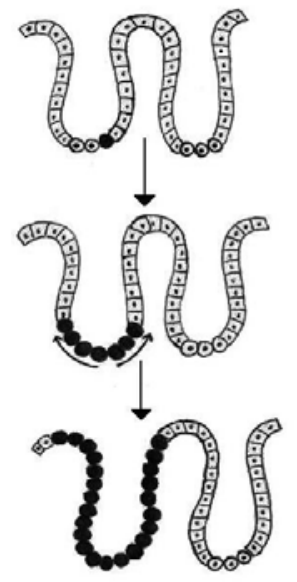

B

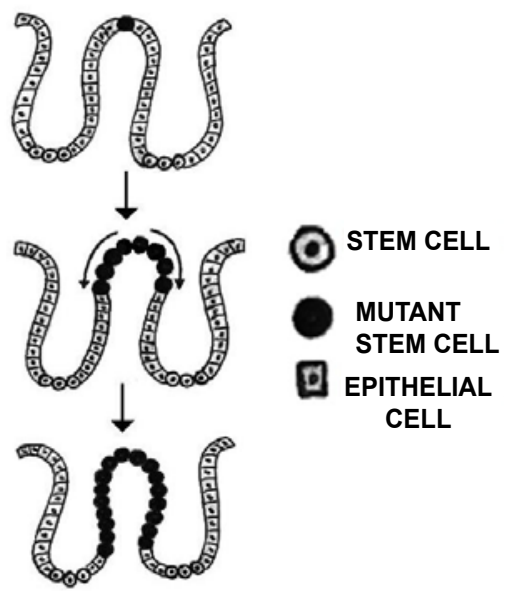

Figure 1: Progressive changes in the CSCs population in the intestinal crypt. Bottom-up (A) and Top-down (B), model of colorectal carcinomas (Adaptive and modified courtesy [82,90]). 
Citation: Roy S, Majumdar APN (2012) Cancer Stem Cells in Colorectal Cancer: Genetic and Epigenetic Changes. J Stem Cell Res Ther S7:006. doi:10.4172/2157-7633.S7-006

Page 4 of 6

form new crypts which subsequently connect to the preexisting normal crypts and ultimately replace them.

\section{Adenoma to Carcinoma Succession}

Adenoma to carcinoma succession is a long and complex process. There is no doubt that CSCs/CSLCs are involved in this process. We have previously shown that colon cancer stem-like cells are present in the premalignant adenomatous polyps as well in normal appearing colonic mucosa [85-87]. Age-related rise in CSC/CSLC in macroscopically normal colonic mucosa suggests a predisposition of the organ to developing colorectal cancer [86]. We also showed that aging increases vulnerability of the colon to carcinogen(s)/toxicant(s) resulting in enrichment of CSCs/CSLCs with increased expression of CSC/CSLC markers: CD44, CD166 ALDH-1 and increased expression of miR-21 an oncomiR [87]. These and other relevant observations led us to suggest that aging is a risk factor for development of colorectal cancer.

\section{Future Directive}

Epigenetic modifications are useful biomarkers for early detections of CRC- (i) especially for asymptomatic tumors; (ii) unlike genetic mutations they can be quantified miRNAs, DNA methylation are now being used for the diagnosis and determination of prognostic responses to chemotherapy in patients with colorectal tumor [88]. Epigenetic modifications are dominating over genetic modifications because of their reversibility and are being used as therapeutic targets. DNMT and HDAC inhibitors are long been in practice as a backup for drug resistance [89]. However, further studies are needed to elucidate genetic and epigenetic changes that occur in CSCs/CSLCs during the progression of CRC.

\section{Acknowledgement}

This work was supported by grants to Dr. Majumdar from the National Institutes of Health/National Institute on Aging (AG014343) and the Department of Veterans Affairs.

\section{References}

1. Ferlay J, Shin HR, Bray F, Forman D, Mathers C, et al. (2010) Estimates of worldwide burden of cancer in 2008: GLOBOCAN 2008. Int J Cancer 127: 2893-2917.

2. American Cancer Society (2012) Cancer Facts and Figures 2012. Atlanta, GA

3. Lynch HT, Smyrk T (1996) Hereditary nonpolyposis colorectal cancer (Lynch syndrome). An updated review. Cancer 78: 1149-1167.

4. Huxley RR, Ansary-Moghaddam A, Clifton P, Czernichow S, Parr CL, et al (2009) The impact of dietary and lifestyle risk factors on risk of colorectal cancer: a quantitative overview of the epidemiological evidence. Int J Cancer 125: $171-180$.

5. Leppert M, Burt R, Hughes JP, Samowitz W, Nakamura Y, et al. (1990) Genetic analysis of an inherited predisposition to colon cancer in a family with a variable number of adenomatous polyps. N Engl J Med 322: 904-908.

6. Balmaña J, Stockwell DH, Steyerberg EW, Stoffel EM, Deffenbaugh AM, et al (2006) Prediction of MLH1 and MSH2 mutations in Lynch syndrome. JAMA 296: $1469-1478$

7. Barnetson RA, Tenesa A, Farrington SM, Nicholl ID, Cetnarskyj R, et al. (2006) Identification and survival of carriers of mutations in DNA mismatch-repair genes in colon cancer. N Engl J Med 354: 2751-2763.

8. Burt RW, Petersen GM (1996) Familial colorectal cancer: diagnosis and management. In: Prevention and Early Detection of Colorectal Cancer edited by Young GP, Rozen P, Levin B , London, England: WB Saunders, 171-194.

9. Jass JR, Whitehall VL, Young J, Leggett BA (2002) Emerging concepts in colorectal neoplasia. Gastroenterology 123: 862-876

10. Gerger A, Zhang W, Yang D, Bohanes P, Ning Y, et al. (2011) Common cancer stem cell gene variants predict colon cancer recurrence. Clin Cancer Res 17 6934-6943.

11. Clarke MF, Dick JE, Dirks PB, Eaves CJ, Jamieson CH, et al. (2006) Cancer Stem Cells--Perspectives on Current Status and Future Directions: AACR Workshop on Cancer Stem Cells. Cancer Res 66: 9339-9344.

12. Rapp UR, Ceteci F, Schreck R (2008) Oncogene-induced plasticity and cancer stem cells. Cell Cycle 7: 45-51.

13. Clevers $H$ (2011) The cancer stem cell: premises, promises and challenges Nat Med 17: 313-319.

14. Dalerba P, Dylla SJ, Park IK, Liu R, Wang X, et al. (2007) Phenotypic characterization of human colorectal cancer stem cells. Proc Natl Acad Sc USA 104: 10158-10163.

15. Sanders MA, Majumdar AP (2011) Colon cancer stem cells: implications in carcinogenesis. Front Biosci 16: 1651-1662.

16. O'Brien CA, Pollett A, Gallinger S, Dick JE (2007) A human colon cancer cell capable of initiating tumour growth in immunodeficient mice. Nature 445: 106110.

17. Roy S, Majumdar AP (2012) Signaling in colon cancer stem cells. J Mol Signal 7: 11 .

18. Kanwar SS, Yu Y, Nautiyal J, Patel BB, Majumdar AP (2010) The Wnt/betacatenin pathway regulates growth and maintenance of colonospheres. Mol Cancer 9: 212.

19. Cairns J (2002) Somatic stem cells and the kinetics of mutagenesis and carcinogenesis. Proc Natl Acad Sci USA 99: 10567-10570.

20. Feinberg AP, Ohlsson R, Henikoff S (2006) The epigenetic progenitor origin of human cancer. Nat Rev Genet 7: 21-33.

21. Magee JA, Piskounova E, Morrison SJ (2012) Cancer stem cells: impact heterogeneity, and uncertainty. Cancer Cell 21: 283-296.

22. Finkel T, Serrano M, Blasco MA (2007) The common biology of cancer and ageing. Nature 448: 767-774

23. Sparks AB, Morin PJ, Vogelstein B, Kinzler KW (1998) Mutational analysis of the APC/beta-catenin/Tcf pathway in colorectal cancer. Cancer Res 58: 11301134

24. Fearon ER, Vogelstein B (1990) A genetic model for colorectal tumorigenesis Cell 61: 759-767.

25. Fearon ER (2011) Molecular genetics of colorectal cancer. Annu Rev Pathol 6: $479-507$.

26. Lengauer C, Kinzler KW, Vogelstein B (1998) Genetic instabilities in human cancers. Nature 396: 643-649.

27. Sjöblom T, Jones S, Wood LD, Parsons DW, Lin J, et al. (2006) The consensus coding sequences of human breast and colorectal cancers. Science 314: 268 274

28. Kinzler KW, Vogelstein B (2002) Colorectal tumors. In: The Genetic Basis of Human Cancer. ( $2^{\text {nd }}$ edn) edited by Vogelstein B, Kinzler KW, 583-612. New York NY: McGraw-Hill.

29. Bonasio R, Tu S, Reinberg D (2010) Molecular signals of epigenetic states. Science 330: 612-616.

30. Bennett-Baker PE, Wilkowski J, Burke DT (2003) Age-associated activation of epigenetically repressed genes in the mouse. Genetics 165: 2055-2062.

31. Lu Q, Qiu X, Hu N, Wen H, Su Y, et al. (2006) Epigenetics, disease, and therapeutic interventions. Ageing Res Rev 5: 449-467.

32. Calin GA, Croce CM (2006) MicroRNA signatures in human cancers. Nat Rev Cancer 6: 857-866.

33. Liu L, Wylie RC, Andrews LG, Tollefsbol TO (2003) Aging, cancer and nutrition: the DNA methylation connection. Mech Aging Dev 124: 989-998.

34. Schulz WA (1998) DNA methylation in urological malignancies (review). Int Oncol 13: 151-167.

35. Reik W, Surani MA (1989) Cancer genetics. Genomic imprinting and embryona tumours. Nature 338: 112-113.

36. Feinberg AP, Vogelstein B (1983) Hypomethylation distinguishes genes of some human cancers from their normal counterparts. Nature 301: 89-92. 
Citation: Roy S, Majumdar APN (2012) Cancer Stem Cells in Colorectal Cancer: Genetic and Epigenetic Changes. J Stem Cell Res Ther S7:006. doi:10.4172/2157-7633.S7-006

Page 5 of 6

37. Greger V, Passarge E, Höpping W, Messmer E, Horsthemke B (1989) Epigenetic changes may contribute to the formation and spontaneous regression of retinoblastoma. Human Genetics 83: 155-158

38. Lujambio A, Ropero S, Ballestar E, Fraga MF, Cerrato C, et al. (2007) Genetic unmasking of an epigenetically silenced microRNA in human cancer cells. Cancer Research 67: 1424-1429.

39. Rennie PS, Nelson CC (1998) Epigenetic mechanisms for progression of prostate cancer. Cancer Metastasis Rev 17: 401-409.

40. Cheah MS, Wallace CD, Hoffman RM (1984) Hypomethylation of DNA in human cancer cells: a site-specific change in the c-myc oncogene. J Natl Cancer Inst 73: 1057-1065.

41. Goelz SE, Vogelstein B, Hamilton SR, Feinberg AP (1985) Hypomethylation of DNA from benign and malignant human colon neoplasms. Science 228: 187190

42. Hibi K, Goto T, Mizukami H, Kitamura YH, Sakuraba K, et al. (2009) Demethylation of the $\mathrm{CDH} 3$ gene is frequently detected in advanced colorectal cancer. Anticancer Res 29: 2215-2217.

43. Chalitchagorn K, Shuangshoti S, Hourpai N, Kongruttanachok N, Tangkijvanich $P$, et al. (2004) Distinctive pattern of LINE-1 methylation level in normal tissues and the association with carcinogenesis. Oncogene 23: 8841-8846.

44. Cui H, Horon IL, Ohlsson R, Hamilton SR, Feinberg AP (1998) Loss of imprinting in normal tissue of colorectal cancer patients with microsatellite instability. Nat Med 4: 1276-1280

45. Greenblatt MS, Bennett WP, Hollstein M, Harris CC (1994) Mutations in the p53 tumor suppressor gene: clues to cancer etiology and molecular pathogenesis. Cancer Res 54: 4855-4878.

46. Toyota M, Ahuja N, Ohe-Toyota M, Herman JG, Baylin SB, et al. (1999) CpG island methylator phenotype in colorectal cancer. Proc Natl Acad Sci USA 96 8681-8686.

47. Yu J, Tao Q, Cheung KF, Jin H, Poon FF, et al. (2008) Epigenetic identification of ubiquitin carboxyl-terminal hydrolase $\mathrm{L} 1$ as a functional tumor suppressor and biomarker for hepatocellular carcinoma and other digestive tumors. Hepatology 48: 508-518.

48. Goto T, Mizukami H, Shirahata A, Sakata M, Saito M, et al. (2009) Aberrant methylation of the p16 gene is frequently detected in advanced colorecta cancer. Anticancer Res 29: 275-277.

49. Yamashita K, Park HL, Kim MS, Osada M, Tokumaru Y, et al. (2006) PGP9.5 methylation in diffuse-type gastric cancer. Cancer Research 66: 3921-3927.

50. Chen J, Röcken C, Lofton-Day C, Schulz HU, Müller O, et al. (2005) Molecular analysis of APC promoter methylation and protein expression in colorectal cancer metastasis. Carcinogenesis 26: 37-43.

51. Wynter CV, Walsh MD, Higuchi T, Leggett BA, Young J, et al. (2004) Methylation patterns define two types of hyperplastic polyp associated with colorectal cancer. Gut 53: 573-580.

52. Jass JR (2007) Classification of colorectal cancer based on correlation of clinical, morphological and molecular features. Hisopathology 50: 113-130.

53. Bartel DP (2004) MicroRNAs: genomics, biogenesis, mechanism, and function. Cell 116: 281-297.

54. Zhu S, Si ML, Wu H, Mo YY (2007) MicroRNA-21 targets the tumor suppressor gene tropomyosin 1 (TPM1). J Biol Chem 282: 14328-14336.

55. Meng F, Henson R, Wehbe-Janek H, Ghoshal K, Jacob ST, et al. (2007) MicroRNA-21 regulates expression of the PTEN tumor suppressor gene in human hepatocellular cancer. Gastroenterology 133: 647-658.

56. Zhu S, Wu H, Wu F, Nie D, Sheng S, et al. (2008) MicroRNA-21 targets tumor suppressor genes in invasion and metastasis. Cell Res 18: 350-359.

57. Löffler D, Brocke-Heidrich K, Pfeifer G, Stocsits C, Hackermüller J, et al. (2007) Interleukin-6 dependent survival of multiple myeloma cells involves the Stat3mediated induction of microRNA-21 through a highly conserved enhancer. Blood 110: 1330-1333.

58. Maggio M, Guralnik JM, Longo DL, Ferrucci L (2006) Interleukin-6 in aging and chronic disease: a magnificent pathway. J Gerontol A Biol Sci Med Sci 61: $575-584$.

59. Yu Y, Kanwar SS, Patel BB, Oh PS, Nautiyal J (2012) MicroRNA-21 induces stemness by downregulating transforming growth factor beta receptor 2 (TGFbetaR2) in colon cancer cells. Carcinogenesis 33: 68-76.

60. Oh PS, Patel VB, Sanders MA, Kanwar SS, Yu Y, et al. (2011) Schlafen-3 decreases cancer stem cell marker expression and autocrine/juxtacrine signaling in FOLFOX-resistant colon cancer cells. Am J Physiol Gastrointest Liver Physiol 301: G347-G355.

61. Yu Y, Kanwar SS, Patel BB, Nautiyal J, Sarkar FH, et al. (2009) Elimination of Colon Cancer Stem-Like Cells by the Combination of Curcumin and FOLFOX Transl Oncol 2: 321-328.

62. Todaro M, Francipane MG, Medema JP, Stassi G (2010) Colon cancer stem cells: promise of targeted therapy. Gastroenterology 138: 2151-2162.

63. Tazawa H, Tsuchiya N, Izumiya M, Nakagama H (2007) Tumor-suppressive miR-34a induces senescence-like growth arrest through modulation of the E2F pathway in human colon cancer cells. Proc Natl Acad Sci USA 104: 15472 15477.

64. Roy S, Levi E, Majumdar AP, Sarkar FH (2012) Expression of miR-34 is lost in colon cancer which can be re-expressed by a novel agent CDF. J Hematol Oncol 5: 58

65. Akao Y, Noguchi S, lio A, Kojima K, Takagi T, et al. (2011) Dysregulation of microRNA-34a expression causes drug-resistance to 5-FU in human colon cancer DLD-1 cells. Cancer Lett 300: 197-204.

66. Yamakuchi M, Lowenstein CJ (2009) MiR-34, SIRT1 and p53: the feedback loop. Cell Cycle 8: 712-715.

67. Yamakuchi M, Ferlito M, Lowenstein CJ (2008) miR-34a repression of SIRT1 regulates apoptosis. Proc Natl Acad Sci USA 105: 13421-13426.

68. Migliore C, Petrelli A, Ghiso E, Corso S, Capparuccia L, et al. (2008) MicroRNAs impair MET-mediated invasive growth. Cancer Res 68: 10128-10136.

69. Raver-Shapira N, Marciano E, Meiri E, Spector Y, Rosenfeld N, et al. (2007) Transcriptional activation of miR-34a contributes to p53-mediated apoptosis. Mol Cell 26: 731-743.

70. Wang GG, Allis CD, Chi P (2007) Chromatin remodeling and cancer, part I: covalent histone modifications. Trends Mol Med 13: 363-372.

71. Bannister AJ, Kouzarides T (2011) Regulation of chromatin by histone modifications. Cell Res 21: 381-395

72. Fraga MF, Ballestar E, Villar-Garea A, Boix-Chornet M, Espada J, et al. (2005) Loss of acetylation at Lys 16 and trimethylation at Lys 20 of histone $\mathrm{H} 4$ is a common hallmark of human cancer. Nat Genet 37: 391-400.

73. Ashktorab H, Schäffer AA, Daremipouran M, Smoot DT, Lee E, et al. (2010) Distinct genetic alterations in colorectal cancer. PLoS One 5: e8879.

74. Tamagawa H, Oshima T, Shiozawa M, Morinaga S, Nakamura Y, et al. (2012 The global histone modification pattern correlates with overall survival in metachronous liver metastasis of colorectal cancer. Oncol Rep 27: 637-642.

75. Zuo X, Morris JS, Shureiqi I (2008) Chromatin modification requirements fo 15-lipoxygenase-1 transcriptional reactivation in colon cancer cells. J Biol Chem 283: 31341-31347.

76. Chen YX, Fang JY, Lu R, Qiu DK (2007) Expression of p21(WAF1) is related to acetylation of histone $\mathrm{H} 3$ in total chromatin in human colorectal cancer. World J Gastroenterol 13: 2209-2213.

77. Li Q, Chen H (2011) Transcriptional silencing of N-Myc downstream-regulated gene 1 (NDRG1) in metastatic colon cancer cell line SW620. Clin Exp Metastasis 28: 127-135.

78. Peláez IM, Kalogeropoulou M, Ferraro A Voulgari A, Pankotai T, et al (2010) Oncogenic RAS alters the global and gene-specific histone modification pattern during epithelial mesenchymal transition in colorectal carcinoma cells. Int $J$ Biochem Cell Biol 42: 911-920.

79. Liu C, Kelnar K, Liu B, Chen X, Calhoun-Davis T, et al. (2011) The microRNA miR-34a inhibits prostate cancer stem cells and metastasis by directly repressing CD44. Nat Med 17: 211-215.

80. Nguyen CT, Weisenberger DJ, Velicescu M, Gonzales FA, Lin JC, et al. (2002) Histone $\mathrm{H} 3$-lysine 9 methylation is associated with aberrant gene silencing in cancer cells and is rapidly reversed by 5 -aza-2'-deoxycytidine. Cancer Res 62 . 6456-6461. 
Citation: Roy S, Majumdar APN (2012) Cancer Stem Cells in Colorectal Cancer: Genetic and Epigenetic Changes. J Stem Cell Res Ther S7:006. doi:10.4172/2157-7633.S7-006

81. Huang J, Dorsey J, Chuikov S, Pérez-Burgos L, Zhang X, et al. (2010) G9a and Glp methylate lysine 373 in the tumor suppressor p53. J Biol Chem 285: 9636-9641.

82. Lamprecht SA, Lipkin M (2002) Migrating colonic crypt epithelial cells: primary targets for Transformation. Carcinogenesis 23: 1777-1780.

83. Shih IM, Wang TL, Traverso G, Romans K, Hamilton SR, et al. (2001) Topdown morphogenesis of colorectal tumors. Proc Natl Acad Sci USA 98: 26402645

84. Cole JW, Mckalea A (1963) Studies on the Morphogenesis of Adenometus Polyps in the Human Colon. Cancer 16: 998-1002.

85. Levi E, Misra S, Du J, Patel BB, Majumdar AP (2009) Combination of aging and dimethylhydrazine treatment causes an increase in cancer-stem cell population of rat colonic crypts. Biochem Biophys Res Commun 385: 430-433.
86. Patel BB, Yu Y, Du J, Levi E, Phillip PA, et al. (2009) Age-related increase in colorectal cancer stem cells in macroscopically normal mucosa of patients with adenomas: a risk factor for colon cancer. Biochem Biophys Res Commun 378 344-347.

87. Nautiyal J, Du J, Yu Y, Kanwar SS, Levi E et al. (2012) EGFR regulation of colon cancer stem-like cells during aging and in response to the colonic carcinogen dimethylhydrazine. Am J Physiol Gastrointest Liver Physiol 302: G655-G663.

88. Goel A, Boland CR (2012) Epigenetics of colorectal cancer. Gastroenterology 143: $1442-1460$

89. Lyko F, Brown R (2005) DNA methyltransferase inhibitors and the development of epigenetic cancer therapies. J Natl Cancer Inst 97: 1498-1506.

90. Leedham SJ, Thliveris AT, Halberg RB, Newton MA, Wright NA (2005) Gastrointestinal stem cells and cancer: bridging the molecular gap. Stem Cell Rev 1: 233-241.
This article was originally published in a special issue, Cancer Stem Cells handled by Editor(s). Fazlul Hoque Sarkar, Wayne State University, USA; Asfar Sohail Azmi, Wayne State University, USA 